\title{
Molecular typing of Listeria spp. isolated from different sources"
}

\author{
Seçil ABAY ${ }^{1}$, Fuat AYDIN ${ }^{1}$, Ahmet Bülent SÜMERKAN ${ }^{2}$ \\ ${ }^{1}$ Department of Microbiology, Faculty of Veterinary Medicine, Erciyes University, Kayseri, ${ }^{2}$ Department of Microbiology, \\ Acıbadem Medical Center, Kayseri, Turkey.
}

Summary: The aim of this study was to determine the presence of Listeria spp. from different sources (beef and sheep minced meat, feces, milk and silage), and perform the genotyping of Listeria spp. strains isolated from these sources and $L$. monocytogenes isolates obtained from Erciyes University, Faculty of Medicine, Department of Microbiology by Rep-PCR using the DiversiLab system. A total of 350 samples were examined for the presence of Listeria spp. by conventional culture method and immunomagnetic separation method, between December 2008 and May 2009. Identification of obtained isolates was made with Microbact 12L Listeria identification test kit (Oxoid, MB1128A) and PCR was used to confirm the L. monocytogenes isolates. Listeria spp. were isolated from $22 \%, 10 \%, 48 \%$ and $16 \%$ of 50 cattle feces, 50 sheep feces, 25 beef minced meat and 25 sheep minced meat samples respectively. No Listeria spp. were obtained from the sheep and cow's milks, bulk tank milks and silage samples examined. In total, 32 Listeria spp. isolates were obtained. Of these isolates, 12 were identified as L. monocytogenes, 12 as L. innocua, 6 as L. grayi and 2 as L. welshimeri. Listeria species were divided into three different genotypic groups designated as A, B, C by Rep-PCR profiles. The same species in the groups were detected as genetically similar at a ratio of $90-99 \%$. High level genotypic relations were determined among the L. monocytogenes strains isolated from cattle-sheep feces, minced meat and human samples. The results reveal the importance of Listeria spp. as a foodborne pathogen, possessing zoonotic potential.

Key words: Cattle, immunomagnetic separation, Listeria spp., Rep-PCR, sheep.

\section{Farklı Kaynaklardan İzole Edilen Listeria Türlerinin Moleküler Tiplendirilmesi}

Özet : Bu çalışmada farklı kaynaklardan (sığır-koyun kıyma ve dışkısı, süt, silaj) Listeria türlerinin varlığının saptanması ve bu kaynaklardan elde edilen izolatlar ile Erciyes Üniversitesi Tıp Fakültesi Mikrobiyoloji Anabilim Dalından temin edilen insan kaynaklı L. monocytogenes izolatlarının Rep-PCR tekniği ile genotiplendirilmesi amaçlandı. Çalışmada Aralık 2008-Mayıs 2009 tarihleri arasında toplam 350 örnek konvansiyonel yöntemler ve immunomanyetik separasyon metodu ile Listeria spp. yönünden incelendi. İzolatların identifikasyonu Microbact 12L Listeria identifikasyon kiti (Oxoid, MB1128A) ile yapıld 1 ve L. monocytogenes izolatlarını doğrulamak için PCR yöntemi kullanıldı. Listeria türleri, 50 sığır dışkı, 50 koyun dışkı, 25 sığır kıyma ve 25 koyun kıyma örneğinden sırasıyla \% 22, \% 10, \% 48, \% 16 oranında izole edildi. İncelenen koyun ve sığır sütleri, tank sütü örnekleri ile silaj örneklerinden Listeria türleri izole edilemedi. Toplamda 32 Listeria spp. izolatı elde edildi. Bu izolatların 12 'si $L$. monocytogenes, 12'si L. innocua, 6's1 L. grayi, 2'si L. welshimeri olarak identifiye edildi. Rep-PCR profillerine göre, Listeria türleri A, B, C olarak dizayn edilen 3 farklı genotipik gruba ayrıldı. Gruplar içerisindeki aynı türlerin \% 90-99 oranında genetik benzerlik gösterdiği tespit edildi. İnsan, kıyma, sığır-koyun dışkı örneklerinden izole edilen L. monocytogenes suşları arasında yüksek düzeyde genotipik yakınlık saptandı. Bu sonuçlar gıda kaynaklı zoonoz bir patojen olan Listeria türlerinin önemini ortaya koymaktadır.

Anahtar sözcükler: İmmunomanyetik separasyon, koyun, Listeria spp., Rep-PCR, sığır.

\section{Introduction}

Listeria are known to be the bacteria responsible for listeriosis, a rare but potentially lethal food-borne infection. The genus Listeria consisted of six species until 2009: Listeria monocytogenes, L. ivanovii, L. innocua, L. welshimeri, L. seeligeri and L. grayi (20). However, recently two other species have been reported: L. marthii (12) and L. rocourtiae (19). Among all the Listeria species, limited numbers of species have medical and veterinary importance. Listeria monocytogenes and Listeria ivanovii are pathogenic (20). However, sporadic human infections due to Listeria seeligeri and Listeria innocua have also been reported $(25,26)$.

Knowledge of the ecology and epidemiology of Listeria spp. can help to determine potential sources of contamination and to prevent the spread of these bacteria in the environment. A wide range of phenotypic and genotypic techniques have been used to identify, classify and type Listeria spp. In genotyping methods, Rep-PCR uses primers that target non-coding repetitive sequences interspersed throughout the bacterial genome (34). The novel development of a commercially available

\footnotetext{
* Summarized by the first author's dissertation and complied with ethics rules.
} 
automated system (DiversiLab, Bacterial Barcodes) has resulted in the standardization of Rep-PCR methodology and has greatly increased its ease of use in the clinical laboratory (14).

The aim of this study was to determine the presence of Listeria spp. from different sources (beef and sheep minced meat, feces, milk and silage) and perform the genotyping of Listeria spp. strains isolated from these sources and L. monocytogenes isolates obtained from Erciyes University, Faculty of Medicine, Department of Microbiology by Rep-PCR using the DiversiLab system.

\section{Materials and Methods}

Samples: A total of 350 samples consisting of feces from sheep (50) and cattle (50); milk from cattle (50), sheep (50), and bulk tank (50); silage (50) and beef (25) and sheep (25) minced meat were examined.

Listeria monocytogenes isolates of human clinical origin: Sixteen L. monocytogenes isolates were obtained from Erciyes University, Faculty of Medicine, Department of Microbiology for Rep-PCR analysis. These strains were isolated from various clinical specimens (blood, cerebrospinal fluid and peritoneum) in cases of sporadic listeriosis between 1991 and 2004.

Standard strain: The reference strain $L$. monocytogenes $1 / 2 \mathrm{~b}$ serotype (RSKK 472, Refik Saydam Hifzıssıhha Institute, Ankara, Turkey) was used as a positive control in this study.

Isolation and identification of Listeria spp.: All samples were added to Listeria enrichment broth (LEB, Oxoid, CM862), then homogenized and incubated for 48 hours at $30^{\circ} \mathrm{C}$ in the presence of $5-10 \% \mathrm{CO}_{2}$ (Anaerocult $\mathrm{C}$, Merck 1.16275). Following incubation, immunomagnetic separation (IMS) was performed to concentrate Listeria spp. according to the manufacturer's instructions with Dynabeads anti-Listeria (Dynal AS, 710.06). After immuno-magnetic separation, $50 \mu \mathrm{l}$ of the LEB were streaked onto the surface of Listeria selective agar (LSA, Oxoid CM856). Isolation procedures of Listeria were performed with conventional methods (28). In addition, Microbact 12L Listeria identification system (Oxoid,
MB1128A) was used for identification. All $L$. monocytogenes isolates identified by phenotypic tests were confirmed using species specific primers. Primers were composed of Primer A (5'-CAT TAG TGG AAA GAT GGA ATG-3') and primer B (5'- GTA TCC TCC AGA GTG ATC GA-3') were used for the amplification of a $730 \mathrm{bp}$ region of the hly gene (11). Amplification conditions were optimized to the thermal cycler (Techne TC-512) and were as follows: $80^{\circ} \mathrm{C}$ for $10 \mathrm{~min}$, an initial denaturation at $94^{\circ} \mathrm{C}$ for $3 \mathrm{~min}$, followed by 30 cycles, each consisting of at $94^{\circ} \mathrm{C}$ for $30 \mathrm{~s}, 55^{\circ} \mathrm{C}$ for $30 \mathrm{~s}$ and $72^{\circ} \mathrm{C}$ for $30 \mathrm{~s}$. Final extension cycle of $2 \mathrm{~min}$ at $72^{\circ} \mathrm{C}$. Amplification products were detected by agarose gel $(1.5 \%)$ electrophoresis performed at $100 \mathrm{~V}$ for $40 \mathrm{~min}$ (EC250-90, Thermo). The gels were stained with $0.5 \mu 1 / \mathrm{ml}$ ethidium bromide and inspected visually under a UV transilluminator (Vilber Lourmat,V03-8464, TCP-20-M) (11).

DNA extraction: DNA from each isolate was extracted using the UltraClean microbial DNA isolation kit (Mo Bio Laboratories, 12224-250) following the manufacturer's instructions.

Rep-PCR DNA fingerprinting: All DNA samples were amplified using the DiversiLab Listeria Kit (Bacterial Barcodes, 270618). Rep-PCR fingerprinting profiles were compared with DiversiLab ${ }^{\circledR}$ (version 3.4) software using the Pearson correlation coefficient (Bacterial Barcodes). The relation was determined by cluster analysis and guidelines provided by the manufacturer (DiversiLab ${ }^{\circledR}$, version 3.4).

\section{Results}

Prevalence of Listeria spp. in different sources: A total of $32(9.14 \%)$ samples were found positive for Listeria spp. in 350 samples. Overall, 32 strains were isolated, of which $12(37.5 \%)$ were L. monocytogenes, 12 (37.5\%) were L. innocua, $2(6.25 \%)$ were L. welshimeri and the remaining $6(18.75 \%)$ were L. grayi. The occurrence and distribution of Listeria species isolated from different sources are shown in Table 1. Listeria spp. could not be isolated from the milk and silage samples.

Table 1: Occurrence and distribution of Listeria species isolated from different sources

Tablo 1: Farklı kaynaklardan izole edilen Listeria türlerinin varlığg ve dağılımı

\begin{tabular}{lccccc}
\hline \multirow{2}{*}{ Source of materials } & $\begin{array}{c}\text { Number of Listeria } \\
\text { positive samples/(\%) }\end{array}$ & \multicolumn{4}{c}{ Number of Listeria species/(\%) } \\
\cline { 3 - 6 } & $11(22 \%)$ & L. monocytogenes & L. innocua & L. welshimeri & L. grayi \\
\hline Cattle feces & $5(10 \%)$ & $-{ }^{\text {a }}$ & $11(100 \%)$ & - & - \\
Sheep feces & $12(48 \%)$ & $5(41.66 \%)$ & $1(8.33 \%)$ & $1(8.33 \%)$ & $5(41.67 \%)$ \\
Minced beef meat & $4(16 \%)$ & $2(50 \%)$ & - & $1(\% 25)$ & $1(25 \%)$ \\
Sheep minced meat & - & - & - & - & - \\
Sheep milk & - & - & - & - & - \\
Cattle milk & - & - & - & - & - \\
Bulk tank milk & - & $12(37.5 \%)$ & $12(37.5 \%)$ & $2(6.25 \%)$ & $6(18.75 \%)$ \\
Silage & $32(9.14 \%)$ & & & - \\
Total & &
\end{tabular}

a: negative 
Table 2: Distribution of Listeria species isolated from beef and sheep minced meat belonging to different supermarkets. Tablo 2: Farklı süpermarketlere ait sığır ve koyun kıymalardan izole edilen Listeria türlerinin dağılımı

\begin{tabular}{lllll}
\hline Supermarkets (M) & Beef minced meat isolates & Species of Listeria & Sheep minced meat isolates & Species of Listeria \\
\hline M1 & BMM1 & L. monocytogenes & SMM1 & L. monocytogenes \\
M2 & BMM2 & L. grayi & - & - \\
M3 & BMM3 & L. monocytogenes & - & - \\
M4 & L. monocytogenes & - & - \\
M5 & L. grayi & - & - \\
M6 & BMM 5 & L. innocua & SMM 2 & Lrayi \\
M7 & BMM 6 & L. monocytogenes & - & - \\
M8 & BMM 7 & L. grayi & - & - \\
M9 & BMM 8 & L. welshimeri & SMM 3 & Lelshimeri \\
M10 & BMM 11 & L. monocytogenes & SMM 4 & L. monocytogenes \\
M11 & BMM 9 & L. grayi & - & - \\
M12 & BMM 10 & L. grayi & - & - \\
\hline
\end{tabular}

a: Negative $\quad$ BMM: Beef minced meat

SMM: Sheep minced meat

The feces samples collected from three dairy farms in different areas were found positive for Listeria spp. Five of the 50 sheep feces samples which were found positive for Listeria spp. were collected from the same sheep farm and all sheep feces isolates were identified as $L$. monocytogenes.

The distribution of Listeria species isolated from beef and sheep minced meat from different supermarkets are presented in Table 2. Although Listeria spp. were only isolated from minced beef samples bought from eight of 25 different supermarkets, Listeria spp. were isolated in both beef and sheep minced meat samples from four markets. While L. monocytogenes strains were isolated from both beef and sheep minced meat bought from two of the supermarkets (M1, M10), L. welshimeri strains were isolated from both beef and sheep minced meat in one of the supermarkets (M9). Furthermore the L. innocua strain was isolated from beef minced meat and the L. grayi strain was isolated from sheep minced meat bought from one supermarket (M6).

Molecular characterization of Listeria spp. by RepPCR: According to the dendrogram results obtained in this study (Fig. 1). Listeria species were divided into three different genotypic groups designated as A, B, C. The isolates in group A were separated into several distinct sub-groups that had variable relative similarities, all above $60 \%$ (Fig. 1). The L. innocua strains, isolated from cattle feces and beef minced meat, and the L. grayi and $L$. welshimeri strains, isolated from sheep and beef minced meat, were classed in Group A. Group B, consisting of L. monocytogenes strains isolated from different sources ( 2 from beef minced meat, 2 from sheep minced meat and 4 of human origin.) had a similarity score of greater than $85 \%$ (Fig. 2) and Group C, consisting of L. monocytogenes strains isolated from different sources ( 3 from beef minced meat, 5 from sheep feces and 12 of human origin) had a similarity score of greater than $90 \%$, (Fig. 2). Although the similarity between L. monocytogenes strains in groups $\mathrm{B}$ and $\mathrm{C}$ was $80 \%$, the similarity between these groups (B and C) and the other group (A) was very low (50\%) (Fig. 1).

\section{Discussion and Conclusion}

In this study, the presence of Listeria spp. in the feces of cattle and sheep was determined as $22 \%$ and $20 \%$ respectively. Previous studies reported that Listeria spp. were found between $0.5 \%$ and $67 \%$ of the isolation rate in cattle and sheep feces $(15,29,30,35,37)$. Our findings were also in this range. For meat samples, 12 of the $25(48 \%)$ beef minced meat and 4 of the $25(16 \%)$ sheep minced meat samples were found positive for Listeria. A wide variety of Listeria spp. isolation rates have been reported in meat samples. The reason for this may be attributed to the differences in hygienic conditions of slaughterhouses, storage and processing in different countries $(4,16,22)$.

No Listeria spp. were obtained from the sheep and cow's milks, bulk tank milks and silage samples examined. Similarly, a low prevalence $(0-5 \%)$ of $L$. monocytogenes in bulk tank milk has been reported from countries such as India (1), Sweden (36), Canada (7), Spain (10), and Finland (15). In contrast, some authors reported a greater prevalence of Listeria spp. in bulk-tank milk than in other milks $(13,32,35)$. In general a low prevalence $(0-6.74 \%)$ of these bacteria in raw milk was reported by several authors $(4,13,18,21)$. Listeria spp. could not be isolated from silage samples in our study. However, a high prevalence of Listeria spp. in silage samples was reported by several authors $(15,35)$.

Reported prevalences of Listeria spp. isolated from different sources vary worldwide; this situation may be the result of several factors, such as safety of the isolation methods, varieties of sampling procedures, experimental methods (15) and geography. 


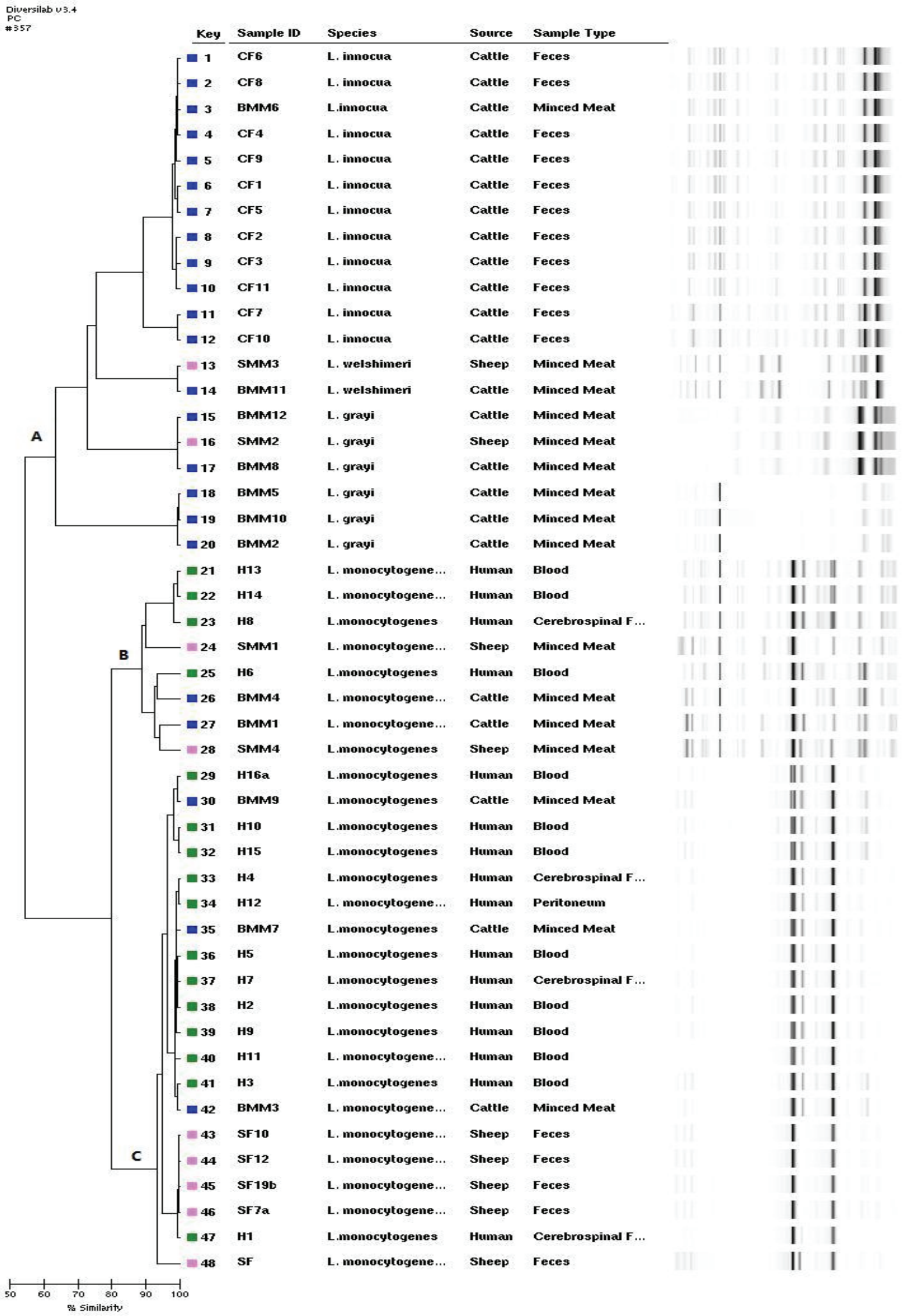

Figure 1: Rep-PCR based dendrogram and virtual gel image fingerprints obtained from 48 Listeria strains isolated from different sources

CF: Cattle feces, SF: Sheep feces, BMM: Beef minced meat, SMM: Sheep minced meat, H:Human

Şekil 1: Farklı kaynaklardan izole edilen 48 Listeria suşundan elde edilen Rep-PCR tabanlı dendrogram ve jel parmak izi görüntüsü 


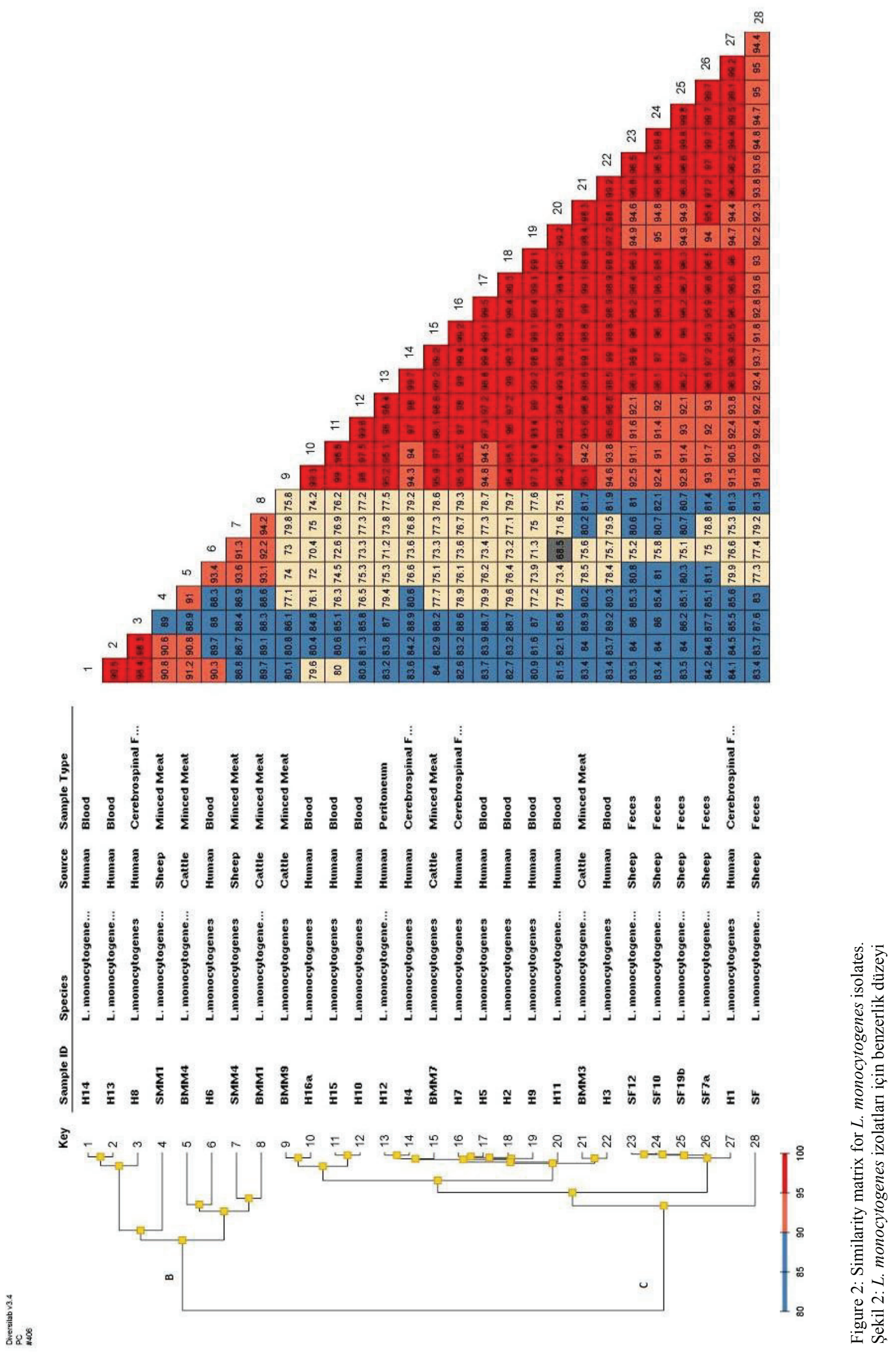


Repetitive element PCR (rep-PCR) has been used for the fingerprinting of microorganisms for twelve years (34) and has been successfully used for typing and distinguishing L. monocytogenes isolates from human and food sources $(17,31)$. Although this genotyping method was used in some studies $(17,38)$ it was previously described using manual assay. This method has recently been standardized and partially automated. The main drawback of the Rep-PCR method using manual assay in the past was lack of reproducibility. The development of a commercially available, automated Rep-PCR assay system such as the DiversiLab system, offers advances in standardization and reproducibility over manual fingerprint generating systems (14).

Although the isolation, identification and molecular typing (RAPD, RFLP and DNA sequencing) of Listeria spp. from different sources have been described $(2,5,6$, 24). There is no available information on the typing of Listeria spp. isolated from human clinical cases and different sources with Rep-PCR in Turkey.

Only two studies on the genotyping of Listeria spp. and L. monocytogenes have been reported with Rep-PCR using the DiversiLab system $(27,33)$. Van Kessel et al. (33) reported that the automated rep-PCR method could be used to differentiate the species of Listeria and they characterized the L. monocytogenes isolates from bulk tank milk using automated rep-PCR.

Roussel et al. (27) presented that the epidemiologically related strains were clustered in the same DT (DiversiLab type) and PFGE type and PFGE was more discriminating than DiversiLab. They also reported that DiversiLab may be useful for tracking the source of contamination in food-processing facilities and their environments. Several studies have been reported on the genotyping of Listeria spp. with non-automated Rep-PCR $(17,38)$. Jersek et al. (17) reported that the Rep-PCR fingerprints (manual) of L. monocytogenes isolates originating from humans and animals have a different genotype from food isolates. Chou and Wang (3) determined that with manual RepPCR the L. monocytogenes isolates of non-catfish seafood and catfish were genetically distinct from human isolates. In contrast to these studies, we recovered $L$. monocytogenes isolates from beef and sheep minced meat and sheep feces samples which were closely related genetically to human isolates. Another important result, according to the Rep-PCR profile the L. welshimeri isolates of sheep and beef minced origin obtained from the same supermarket (SMM 3 and BMM 11) presented 99.4\% genetic similarity. Therefore, cross-contamination in meat and meat products with Listeria in the supermarket might be responsible for the greater similarity seen in our study. The L. innocua isolate (BMM 6) of beef minced meat origin and other $L$. innocua isolates of cattle feces origin were classed in the same group with $99 \%$ similarity. Hence, this result showed that the carcass can be contaminated with Listeria spp. of fecal origin.

Among the molecular typing methods, PFGE has been one of the most frequently used in epidemiological investigations of Listeriosis $(8,9,23)$. The Rep-PCR system using DiversiLab has some additional advantages over PFGE. For example, it is rapid, easy to use, cost effective, reproducible and throughout the whole analysis procedure one person is sufficient. Also, a large number of strains can be analyzed in one day and standardized reagents are used in this method.

In conclusion, Listeria carriers of animal feces should be considered as a potential risk for the epidemiology of listeriosis. Molecular analysis of Listeria species from different sources in our country needs to be fully elucidated. For this reason, many more isolates should be typed with two or more different molecular methods. The results strengthen the significance of Listeria spp. as a foodborne pathogen, possessing zoonotic potential.

\section{Acknowledgements}

This research was supported by the Scientific Research Council of Erciyes University, Kayseri, Turkey (Project No.TSD-08-319).

\section{References}

1. Adesiyun AA, Webb LA, Romain H, Kaminjolo JS (1996): Prevalence of Salmonella, Listeria monocytogenes, Campylobacter spp., Yersinia enterocolitica and Cryptosporidium spp. in bulk milk, cows' faeces and effluents of dairy farms in Trinidad. Rev Elev Med Vet Pays Trop, 49, 303-309.

2. Atıl E, Ertas HB, Ozbey G (2011): Isolation and molecular characterization of Listeria spp. from animals, foood and environmental samples. Veterinarni Medicina, 56, 386-394.

3. Chou CH, Wang C (2006): Genetic relatedness between Listeria monocytogenes isolates from seafood and humans PFGE and Rep-PCR. Int J Food Microbiol, 110, 135-148.

4. Dhanashree B, Otta SK, Karunasagar I, Goebel W (2003): Incidence of Listeria spp. in clinical and food samples in Mangalore, India. Food Microbiol, 20, 447453.

5. Dumen E, Issa G, Ikiz S, Bagcigil F, Ozgur Y, Kahraman T, Ergin S, Yesil O (2011): Determining existance and antibiotic susceptibility status of Listeria monocytogenes isolated from dairy products, serological and moleculer typing of the isolates. Kafkas Univ Vet Fak Derg, 17, 111-119

6. Ertas HS, Seker E (2005): Isolation of Listeria monocytogenes from fish intestines and RAPD analysis. Turk J Vet Anim Sci, 29, 1007-1011.

7. Fedio WM, Jackson H (1990): Incidence of Listeria monocytogenes in raw bulk milk in Alberta. Food Res Int, 23, 236-238.

8. Fugett EB, Schoonmaker-Boop D, Dumas NB., Corby J, Wiedmann M (2007): Pulsed Field Gel Electrophoresis 
(PFGE) analysis of temporally matched Listeria monocytogenes isolates from human clinical cases, foods, ruminant farms and urban and natural environments reveals source-associated as well as widely distributed PFGE types. J Clin Microbiol, 45, 865-873.

9. Garrido V, Torroba L, Garcia-Jalon I, Vitas AI (2008): Surveillance of Listeriosis in Navarre, Spain, 1995-2005Epidemiological patterns and characterization of clinical and food isolates. Eurosurveillance, 13, 1-6.

10. Gaya P, Sanchez J, Medina M, Nunez M (1998): Incidence of Listeria monocytogenes and other Listeria species in raw milk produced in Spain. Food Microbiol, 15, 551-555.

11. Gouws AP, Liedemann I (2005): Evaluation of Diagnostic PCR for the detection of L. monocytogenes in food products. Food Technol Biotechnol, 43, 201-205.

12. Graves LM, Helsel LO, Steigerwalt AG, Morey RE, Daneshvar MI, Roof SE, Orsi RH, Fortes ED, Milillo SR, den Bakker HC, Wiedmann M, Swaminathan B, Sauders BD (2010): Listeria marthii sp. nov., isolated from the natural environment, Finger Lakes National Forest. Int J Syst Evol Microbiol, 60, 1280-1288.

13. Hamdi TM, Naim M, Martin P, Jacquet C (2007): Identification and molecular characterization of Listeria monocytogenes isolated in raw milk in the region of Algiers. Int J Food Microbiol, 116, 190-193.

14. Healy M, Huong J, Bittner T, Lising M, Frye S, Raza S, Schrock R, Manry J, Renwick A, Nieto R, Woods C, Versalovic J, James R, Lupski JR (2005): Microbial DNA typing by automated repetitive-sequence-based PCR. J Clin Microbiol, 43, 199-207.

15. Husu JR (1990): Epidemiological studies on the occurrence of Listeria monocytogenes in the feces of dairy cattle. Zentralbl Veterinarmed B, 37, 276-282.

16. Jalali M, Abedi D (2008): Prevalence of Listeria species in food products in Isfahan, Iran. Int J Food Microbiol, 122, 336-340.

17. Jersek B, Gilot $\mathbf{P}$, Gubina $\mathbf{N}$, Klun J, Mehle E, Tcherneva N, Rijpens N, Herman L (1999): Typing of Listeria monocytogenes strains by repetitive element sequence-based PCR. J Clin Microbiol, 37, 103-109.

18. Kalorey DR, Warke SR, Kurkure NV, Rawool DB, Barbuddhe SB (2008): Listeria species in bovine raw milk: A large survey of Central India. Food Control, 19, 109-112.

19. Leclercq A, Clermont D, Bizet C, Grimont PA, Le Flèche-Matéos $\mathrm{A}$, Roche SM, Buchrieser $\mathrm{C}$, CadetDaniel V, Le Monnier A, Lecuit M, Allerberger $\mathbf{F}$ (2010): Listeria rocourtiae sp. nov. Int J Syst Evol Microbiol, 60, 2210-2214.

20. Liu D (2006): Identification, subtyping and virulence determination of Listeria monocytogenes, an important foodborne pathogen. J Med Microbiol, 55, 645-659.

21. Massa SM, Cesaroni D, Poda G (1990): The incidence of Listeria spp. in soft cheeses, butter and raw milk in the province of Bologna. J Appl Microbiol, 68, 153-156.

22. Molla B, Yilma R, Alemayehu D (2004): Listeria monocytogenes and other Listeria species in retail meat and milk products in Addis Ababa, Ethiopia. Ethiop $\mathrm{J}$ Health Dev, 18, 208-211.
23. Neves E, Lourenco A, Silva AC, Coutinho R, Brito L (2008): Pulsed Field Gel Electrophoresis (PFGE) analysis of Listeria monocytogenes isolates from different sources and geographical origins and representative of the twelve serovars. Syst Appl Microbiol, 31, 387-392.

24. Ozbey G, Ertas HB, Kok F (2006): Prevalence of Listeria species in camel sausages from retail markets in Aydin province in Turkey and RAPD analysis of Listeria monocytogenes isolates. Irish Vet J, 59, 342-344.

25. Perrin M, Bemer M, Delemare C (2003): Fatal Case of Listeria innocua Bacteremia. J Clin Microbiol, 41, 53085309.

26. Rocourt, J, Hof H, Schrettenbrunner A, Malinverni R, Brille J (1986): Méningite purulente aigüe à Listeria seeligeri chez un adulte immunocompétent. Schweiz Med Wochenschr, 116, 248-251.

27. Roussel S, Félix B, Colanéri C, Vignaud ML, Dao TT, Marault M, Brisabois A (2010): Semi-Automated Repetitive-Sequence-Based Polymerase Chain Reaction Compared to Pulsed-Field Gel Electrophoresis for Listeria monocytogenes subtyping. Foodborne Pathog Dis, 7, 10051012.

28. Seeliger HPR, Jones D (1986): Listeria. 1235-1245. In: Sneath PHA, Mair N, Sharpe ME, Holt JG (Eds), Bergeys Manual of Systematic Bacteriology. Williams and Wilkins, Baltimore.

29. Skovgaard N, Morgen CA (1988): Detection of Listeria spp. in faeces from animals, in feeds, and in raw foods of animal origin. Int J Food Microbiol, 6, 229-242.

30. Unnerstad H, Romell A, Ericsson H, Danielsson-Tham ML, Tham W (2000): Listeria monocytogenes in faeces from clinically healthy dairy cows in Sweden. Acta Vet Scand, 41, 167-171.

31. Van Coillie E, Werbrouck H, Heyndrickx M, Herman L, Rijpens NJ (2004): Prevalence and typing of Listeria monocytogenes in ready-to-eat food products on the Belgian market. J Food Prot, 67, 2480-2487.

32. Van Kessel JS, Karns JS, Gorski L, McCluskey BJ, Perdue ML (2004): Prevalence of Salmonella, Listeria monocytogenes, and fecal coliforms in bulk tank milk on US dairies. J Dairy Sci, 87, 2822-2830.

33. Van Kessel JS, Karns JS, Gorski L, Perdue ML (2005): Subtyping Listeria monocytogenes from Bulk Tank Milk Using Automated Repetitive Element-Based PCR. J Food Prot, 68, 2707-2712.

34. Versalovic J, Koeuth T, Lupski JR (1991): Distribution of repetitive DNA sequences in eubacteria and application to fingerprinting of bacterial genomes. Nucleic Acids Res, 19, 6823-6831.

35. Vilar MJ, Yus E, Sanjuan ML, Dieguez FJ, RodriguezOtero JL (2007): Prevalence of and risk factors for Listeria species on dairy farms. J Dairy Sci, 90, 50835088.

36. Waak E, Tham W, Danielsson-Tham ML (2002): Prevalence and fingerprinting of Listeria monocytogenes strains isolated from raw whole milk in farm bulk tanks and dairy plant receiving tanks. Appl Environ Microbiol, 68, 3366-3370.

37. Weber A, Potel J, Schafer-Schmidt R, Prell A, Datzmann C (1995): Studies on the occurrence of Listeria 
monocytogenes in fecal samples of domestic and companion animals. Zentralbl Hyg Umweltmed, 198, $117-$ 123.

38. Wojciech L, Kowalczyk K, Staroniewicz Z, Kosek K, Molenda J, Ugorski M (2004): Genotypic characterization of Listeria monocytogenes isolated from foodstuffs and farm animals in Poland. Bull Vet Inst Pulawy, 48, 427-435.
Geliş tarihi: 14.07.2011 / Kabul tarihi: 10.01.2012

\author{
Address for correspondence: \\ Assist Prof. Dr. Seçil Abay, \\ Erciyes University \\ Faculty of Veterinary Medicine \\ Department of Microbiology \\ 38090 Kayseri, Turkey \\ E-mail: sabay@erciyes.edu.tr
}

